\title{
The Deconstruction of Patriarchal Power against Nature and Women in the Indonesian Novels
}

\author{
Wiyatmi, Maman Suryaman, Esti Swatikasari ${ }^{1}$ \\ ${ }^{1}$ The Department of Indonesian Language Education and Literature, Faculty of Languages and Arts, Yogyakarta \\ State University \\ Correspondence: Wiyatmi. E-mail: wiyatmi@uny.ac.id
}

Received: October 19, 2017

Accepted: October 27, 2017 Online Published: January 29, 2018

doi:10.5539/ass.v14n2p18

URL: https://doi.org/10.5539/ass.v14n2p18

\begin{abstract}
This study aims to identify and understand the deconstruction of the patriarchal ideology power to the nature and women which is portrayed in the Indonesian novels, using the perspective of ecofeminism. The data source is the Indonesian novels that raise issues associated with women's nature. This study used a qualitative design to scrutinize the patriarchal power over nature, environment, and women in the Indonesian novels. Of the nine novels studied (Bilangan Fu, Manjali dan Cakrabirawa, Maya, Partikel, Isinga, Lemah Tanjung, dan Amba, Bunga, and Api Awan Asap, the following findings are obtained. (1) The studied novels describe the deconstruction of the patriarchal power that led to the massive exploration and exploitation of natural resources and cultural heritage and to disremember the values of local wisdom, (2) the novels show a tendency written by the authors with ecofeminism as the basic aesthetic writing of the novel.
\end{abstract}

Keywords: ecofeminism, deconstruction, Indonesian novels, patriarchy

\section{Introduction}

Nature and environment are essential for sustaining lives on this earth. The quality and welfare of human life cannot be separated from the natural conditions and environment in which they live. Various natural and environmental problems which occurred lately, as the impact of global climate change has affected human life. The report of the Human Development Report (2007) has stated that due to global warming in 2000-2004, about 262 million people become victims of climate disasters, and $98 \%$ of it, are the people in the third world countries. The disaster occurred as a result of temperature increase of 3-4 degrees Celsius that caused 350 million people worldwide lost their homes because of flooding. In addition, 334 million people are potentially affected by tropical storms due to the increased sea water temperature (Hunga, in Candraningrum, 2013: ix). Indonesia is also not safe from disaster, floods and landslides that hit various regions in Indonesia, mostly occured also because of extreme climate change that is less anticipated.

Global climate changes occurred due to human intervention which often do not appreciate nature. Even the development programs also often violate the rules of the Environmental Impact Statement. If this is allowed to continue, the expected result will endanger the survival of human lives and other living creatures. Environmental crisis, will cause misery to human beings, especially women. This is because women in general, have a duty and a very big role in maintaining the continued existence of the household, including the family food security. In a family, a woman is responsible to process and serve food, in addition to caring for the family and children.

In this regard, the campaign and establishing values of love of the natural environment should always be carried out and advocated. The campaign, can be made not only directly into real action on the field, as the environmental activists do, but it can also be done through literature and art that bring awareness of love of the environment without forgetting the position of women. In the paradigm of the humanities, the study focused linkages between nature, the environment, the position and the presence of women is known as ecofeminism.

Ecofeminism was introduced by Francoide d'Eaubonne through a book entitled Le Feminism ou la Mart (Feminism or Death), which was first published in 1974 (Tong, 2006: 366). In her book, she put forward the relationship between the oppression of nature with the oppression of women (Gaard, 1993: 13). In patriarchy, women and nature are seen as objects and properties worthy of being exploited (Candraningrum, 2013: 4). Ecofeminism seeks to show the relationship between all forms of human oppression, particularly of women and nature. In this case, ecofeminism view is that women are culturally associated with nature. There is a conceptual 
relationship, symbolic and linguistic connections between feminism and ecological issues (Tong, 2006: 350). Because patriarchy views women and nature as an object and a property to be exploited (Candraningrum, 2013: 4), then ecofeminism was born as a social movement that has strong ideology in opposing the exploitation of women and nature, including economic growth that does not pay attention to the sustainability of ecosystems (Candraningrum, 2013: 4). According to ecofeminism, patriarchy has developed a categorical strategy to justify exploitation, i.e heaven / earth, mind / body, male / female, human / animal, spirit / goods, culture / nature, white / colorless, and others, in this case are in the final position of an object that may be an arbiter and arbitrarily exploited, set up, and made a profit from it. Products from these categories then gave birth to the female body capitalism, capitalism as natural earth and everything in it is not seen as living beings but as a source of capital and investment fundamentals (Candraningrum, 2013: 4-5).

As one of the cultural works, literary works, including novels in Indonesia cannot be separated from the phenomena that occur in society. A number of literary novels were written to respond and redefine the various phenomena that occur in the community, including the phenomena of nature crisis, the environment as a direct or indirect impact on the position and existence of women. Some instances of novel that describe it, for example, are the novel Amba by Laksmi Pamuntjak (2012), which tells the exploitation of forests and natural resources in Buru Island caused by the migrants, Namaku Teweraut by Ani Sekarningsih, which requires women in Papua who would have a baby must stay in a special hut in the woods away from the village, and Api Awan Asap by Korrie Layun Rampan that criticizes excessive deforestation in the interior of Borneo.

The suffering and death of women due to the exploitation of nature and the marginalization of women depicted in the novel show the patriarchal power over nature, environment, and women. If the power of patriarchy is not confronted and stopped, it is afraid that there will be more losses. Nature and environmental damage resulted in the emergence of a variety of disasters, likewise women are also increasingly suffering. It can even lead to death. Patriarchy is a system of relations between the sexes which is based on the legal paternity. Walby (1989: 213-220) explains that patriarchy is a system of social structures, practices which put the men in a dominant position, to oppress and exploit women.

Through literary writings, writers try to criticize disasters and environmental damage caused by human activities, which directly or indirectly cannot be separated from the power of patriarchy. Through the voices of character and the narrator, writers attempt to deconstruct the patriarchal power that caused the disaster and the destruction of nature. Based on this background, this study will examine how the power of patriarchy impact on the exploitation of and violence against nature and women is portrayed in the Indonesian novels. Through this research, how the Indonesian novels voiced deconstruction of the patriarchal power that is behind the exploitation and violence of nature, the environment, and women detrimental to the welfare and human survival can be understood.

\section{Material Studies}

This study aims to identify and understand the deconstruction of the power of patriarchal ideology on nature, the environment, and women portrayed in the Indonesian novels, which is seen as a cultural product that records the social phenomena that occur in the community. This research is in the area of scientific study of literature (reviewing literature/novel), social science (studying the problem of women in society), and environmental sciences (examining the relationship between the environment and man). Therefore, the results are expected to have contribution to the development of interdisciplinary science. This research uses nine Indonesian novels as a study material. The novels are Bilangan Fu, Manjali dan Cakrabirawa, Maya, Partikel, Isinga, Lemah Tanjung, Amba, Bunga, and Api Awan Asap.

\section{Method}

The design used in this research is descriptive qualitative, which is used to dismantle (deconstruct) the existence of patriarchal power over nature, the environment, and women in the Indonesian novels. Data were analyzed using qualitative discourse analysis approach to ecofeminism through categorizing, tabulating, and inference. Categorization is used to classify data based on predefined categories, namely awareness on the ecofeminism contained in the choice of words, sentences, discourse used in the text of the studied novel. Tabulation is used to encapsulate the entire data in tabular form. Inference is used to interpret and summarize the results of research according to the research problems.

\section{Results and Discussion}

The results showed that there are (1) deconstruction of the patriarchal power that led to the exploration and exploitation of nature, (2) the presence of the ecofeminism school of thought as an insight into the aesthetics of 
writing a novel.

\subsection{The Deconstruction of the Patriarchal Power as the Cause of the Exploitation and Exploration of the Nature}

The deconstruction of the exploration and exploitation of natural and cultural heritage is massively present in the novels of Bilangan Fu, Manjali dan Cakrabirawa, and Maya, Partikel, Isinga, Lemah Tanjung, and Amba. From these seven novel, the efforts to deconstruct the view that nature is something that is provided to be used by humans since nature is regarded as a source of capital and fundamental investment, is evident (Candraningrum, 2013: 4-5). Through the characters, the novels that were examined showed that this view is not correct because, if nature is explored and exploited massively and continuously without regard to the preservation and regeneration over time, it will be dying. Therefore, a number of characters in the studied novel, struggled to deconstruct the view.

In a series of novels, Bilangan Fu, Manjali dan Cakrabirawa, dan Maya depicted environmental damage caused by the actions of the climbers who do not understand the ethics of climbing, exploration and exploitation of the teak forests and Limestone Mountains in Sewugunung, and the destruction and theft of antiquities in the region of Calwanarang temple. Dirty rock climbing activities that are damaging and destroying the cliff is conducted by Sandi Yuda and his friends. They do the dirty rock climbing. Dirty rock climbing term used to describe the rock climbing which does not consider the preservation of nature because they are using tools such as rock climbing drill, peg, nail that wound the cliffs, resulting in the destruction of the cliffs. Parang Jati's character was then, present as someone who tried to educate the dirty rock climbers that their actions had been destroying the nature. Instead, Parang Jati introduced the concept of clean climbing, i.e rock climbing without the use of tools that destroy and injure nature. In this case, Parang Jati even equated the practice of dirty rock climbing as an act of rape against nature, raping the motherland. The following data shows how Parang Jati deconstructed dirty rock climbing practices done by Sandi Yuda and his friends.

For us rock climbing is a rite of passage of becoming a real man. Cliffs are stonemarks. Stonemarks are phallus. But that runt showed that our cliffs are womb....

With his damn clear eyes, he said: what are you trying to conquer, that you consider as an enemy, nothing but feminity. Yes. The rock cliffs that you drill and nail....

"Yuda. You're already used to drilling and nailing girls on bed. With cliffs please use other approaches." (Utami, 2008:37).

From these quotations, contrast views are evident, even opposites, in rock climbing between Sandi Yuda and his colleagues with Parang Jati, between dirty and clean climbing. Parang Jati considered rock climbing using tools to hurt the cliff, as if conquering and raping girls. In the perspective of ecofeminism, it shows that the Parang Jati regarded nature, cliffs, identical to the female body. Therefore, rock climbing should be done without tools, injuring and raping cliffs, even asking cliffs for a dialogue.

"But a real climber must converse with the cliffs. Thus, what he intends to conquer is the cliffs itself. A real climber will be succeed if he doesn't hurt the cliffs. If he does, what is the difference with a scum?

"Thief and burglars rape. But a real soldier or gentleman copulates in an intimate dialogue." (Utami, 2008:81).

The concept of clean climbing embraced by Parang Jati deconstructs the practice of rock climbing done by Sandi Yuda and his colleagues, including the military. Moreover, Parang Jati also deconstructs the Sandi Yuda's view that, perhaps, who is also in accordance with the general view, the cliff that they climb is a milestone, a symbol of the phallus, phallic object. In the view of Parang Jati, climbing is a symbol of garba, the womb of mother earth.

In addition to bringing around the rock climbers so that they do not climb with the way that wounded and raped the nature, the deconstruction of the power of patriarchy on nature and the environment is also evident upon Parang Jati had to deal with the businessman and authority that cut down the teak trees in the forests that are protected and the excessive mining of limestone in Sewugunung. In this case, Parang Jati deconstructed the patriarchal logic that regards nature and everything not as a living being, but as a source of capital and fundamental investment (Candraningrum, 2013: 4-5), so that it can be explored and exploited as much as possible. The rescue mission on nature and the environment is run by Parang Jati as an assignment from his adoptive father, Suhubudi, who regarded nature as the womb for human life.

You were saved in the forest, on the cliffs of these rock mountains that shed the thirteen springs for this village. Thus, you must save them: the forest, limestone mountains that shed the thirteen springs. The 
protected you, you must protect them. (Utami, 2008:290).

Parang Jati was originally a baby found in the springs by Mbok Manyar, the guardian of the spring in the village of Sewugunung, and was subsequently handed over to Suhubudi. From these quotations, it seems that Suhubudi stated that the nature is the second womb that protects men, a view that ultimately became the underlying view of Parang Jati and he tried to realize them in his act. Therefore, when the teak forests and limestone hills in Sewugunung were massively exploited by miners and large companies and is protected by the village chief, Parang Jati was the first to dare to invite the head of the village to stop the project.

Parang Jati used this occasion to discuss the murky springs in the village. About half of the springs are dirty and turned brown, because of the forests uphill are cut down. "Can we do something about the logging?" he desperately acclaimed. "The large scale mining also damages the ecosystem of this area," and we shall invite Mr. Pontiman to be present tomorrow's hearing conducted by those researchers. So that Mr. Pontiman knows that the outside world appreciates this area, while the village chief doesn't. Mr Pontiman answered in his eccentric way..., the first word came from his mouth was: agree. He agreed with all Parang Jati said. But.... things are not as simple as that, Jati... This monetary crisis made the worst of our people..., (Utami, 2008:292)

Of course, the village chief refused Parang Jati's requests, because he is part of the project.

Pontiman Sutalip is the name of the chief of the village. A little Julius Caesar. He is an ex-army who for his almost entire life became the village chief in the Sewugunung village. It is a real data that $\mathrm{I}$ have been suspecting.... Lately I heard that he might be the one behind the illegal and legal logging in Sewugunung. His position is to secure the line of business and profit distribution to the "right hands." (Utami, 2008:171).

....because the chief declared a clearance for the mining company in Sewugunung. He also secretly controls the greddy logging which now has become incontrollable. Mr. Pontiman is the primary agent in this region, he is going to be the one who starts the destruction of ecosystem. (Utami, 2008; 391).

From these quotations, it appears that the village chief of Sewugunung and the owner of the company are the symbols of the power of patriarchy who became a destroyer agent of ecosystems. Ecofeminism considers that the exploitation of nature as a manifestation of earth capitalism, a product of patriarchy that views nature and its contents as a source of capital and investments (Candraningrum, 2013: 5). That is the very thing opposed by Parang Jati. To fulfill his mission, Parang Jati worked together with a number of geological and cultural researchers from universities, especially from ITB (Institut Teknologi Bandung) and UGM (Universitas Gadjah Mada) and environmental agencies, until finally the Ministry of Environment prohibited mining in the Sewugunung hills.

In this year, Parang Jati and a team of researchers of Goa Hu have managed to attract public attention about the issue of Sewugunung. They have managed to involve several environmental agencies, the wider intellectual world, and activists of customary rights to reduce the rate of excavation. The Environment Ministry has declared the letter to stop the mining because it does not have the requisite environmental impact assessment. I must admit that Parang Jati was very persistent. Just as he had our repentance from becoming dirty climbers to the clean climbers, now I see that the proposals in his Cultural Strategy started to become the platform of demands ... Utami, 2008:451).

From these quotations, it appears that through the characters of Parang Jati, Suhubudi, Mbok Manyar, the geologist and environmentalist Bilangan $\mathrm{Fu}$ was written to deconstruct the power of patriarchy, which revolved on the rock climbers who violated the ethics of rock climbing and the individuals and groups, even institutionalized exploitation of nature and the environment without considering the preservation of the ecosystem. From a number of findings that have been described above, we see that Bilangan Fu was written with the awareness of ecofeminism adopted by its author.

In Manjali and Cakrabirawa, the deconstruction of the power of the patriarchy, is also visible when Parang Jati together with Marja helped Mrs. Murni (aka Satinem) who lived in the woods near Calwanarang Temple to find her husband's grave. Murni was a former member of Gerwani, while her husband, Sarwengi was a Cakrabirawa force members killed by the security forces for alleged involvement in the New Order 30th September Movement, 1965. After her release from the women jail in Plantungan, Murni lived in the woods while looking for information of where her husband is buried. Before finally helping her finding the grave, inadvertently, Marja and the Parang Jati got acquainted with Murni, a former member of Gerwani who lived in the forest. In the era of the New Order, Murni and her husband, were considered as enemies to be destroyed by the government. They are people who were excluded by the patriarchal power taking form as the military power of the New Order. 
Murni was imprisoned in Plantungan for ten years. When she was finally released, she crept to find someone named Haji Samasiman, who lived in the mountains on the border of Central Java and East. This man visited her three times in the detention. In his first visit. Haji Samadiman reported that Sarwengi was shot dead not far from his garden. The body was buried a hole that Sarwengi dug himself before a bullet went through his head. Murni came to inquire where exactly the tomb of her husband is. But Haji Samadiman had died. Murni did not dare to ask anyone about this matter, because she knows everything related to him will be filthy. Not a clean environment, in terms of the Soeharto's regime... (Utami, 2010:150).

That woman was on his knees. And on her lap was a man who fell asleep. An officer who was just lifted of the well. The face of deep mud coated. Just like newborn, covered in gore.

Thirty years ago, a bullet went through his head. Then blood covered his face. His head drooped, imagining the lap where he could lull himself. In the long sleep.

I have returned, sarwengi. I have come home.

I am home. (Utami, 2010:238).

In the perspective of ecofeminism, the assistance and helps from Parang Jati, Marja, and Suhubudi to Murni, who exiled herself in the forest is a form of deconstruction of the patriarchal power over nature and the marginalized women. They are not afraid suspected of being part of the PKI and Cakrabirawa, for helping Murni, as the people around the forest and Calwanarang temple sites fear about when they are associated the PKI and Cakrabirawa.

In the novel Isinga, the deconstruction of the patriarchal power over nature, the environment, and the woman was evident at the character of Irewa who became a listener outside the classroom when Rev. Ruben teaches teenage boys in the jungles of Papua. Moreover, Irewa is different with other women in the jungles of Papua in general, who do not dare to take the fight against gender construction that led to their husband's authorithy. Irewa is described as a woman who has the courage to go against her husband's authority. In Isinga female education also plays a role in deconstructing patriarchal power.

In Megafu, women are not considered to be respectful. That's why, women only regard other women. They cannot expect it from anyone else. With this last decision, Irewa felt better. Her heart beats freer. Her feet feel lighter. She puts on her clothes again... (Herliany, 2015: 142-143).

Irewa's deconstruction performed not only in the area of awareness, but also in action. In Isinga it was told that HIV AIDS eventually became disease that affected a number of people in the Yar District due the brothel operating in the area. Malon, Irewa's husband who frequently visited brothel, eventually transmited the disease to his wife. Significantly, during the last few years, Papua has become prone to HIV AIDS. According to the Chief Medical Officer of Papua, Aloysisu Giyai, the data on the number of HIV AIDS in Papua Province in 2015 reached 20.145 people, $90 \%$ of which occured through sexual intercourse (kabarpapua.co/penularan-hivaids).

The beginning of the outbreak of HIV AIDS in the Yar District, where Irewa and their families live, started with the incoming flux of a number of people from outside Papua who came to seek expensive eaglewood. Previously, the Papuans did not know that there are expensive trees in the area (Herliany, 2015: 145). Besides the loggers, other group of migrants came from other islands, who eventually settled in Papua. Public facilities were emerging, including brothel. As a result, HIV-AIDS was a widespread-outbreak. To prevent the spread of HIV AIDS, Irewa, assisted by her twin brother, Dr. Jingi and the support head of the County, Madame Selvi, they conducted counseling to cope with and prevent such outbreak.

There are many things Irewa need to talk about. Irewa who used to see how people study in the "one year school" is a teacher herself. Her speech is bold and attentive. The Javanese woman always supports what Irewa says, that women must stand up against men. Other women who have been treated badly by their husbands also support.... These women had also made a plan to pay a visit to the green light house and drive out all the prostutites living there... (Herliany, 2015: 157-158)

Irewa just keeps doing her works. Keeping the harmony. With Jingi's help, she educates women in the deep jungle... Jingi adds about health knowledge. Jingi and Irewa keep moving from one region to another. Irewa keeps it in balance with her works at home.... (Herliany, 2015:159).

The deconstruction of the patriarchal power over nature and the environment that has a direct impact on women is evident at Isinga, it is also conveyed through the voices of women in the wilderness. They have lost a source of food, medicines, and income from logging in forests that did not address the basic needs of indigenous 
communities.

Mama retells different stories, about her land and the village of her which is now gone.

“Child. Listens to Mother's story. My live is hard now. The sago trees are gone, replaced with palm trees. No more food. Mama cannot make sago balls for the family. Mama cannot hold a customary gathering anymore, no more ingredients for making medicine. No more things to make clothes for dancing, making knits and yarn. We do not eat palm trees, right?" The mothers say that since the old time, the elders taught us to respect the nature. Respecting others and land, forest, land is mama.

“Could we, the children on earth, kill a Mama?”(Herliany, 2015:163).

The quote shows that forest controlled by the government and certain employers, with the replacement of certain crops would cause harm to the indigenous people, especially women. Replacement of sago with palm tree is to eliminate the source of staple foods, medicines, fabrics and crafts materials. It indirectly also will kill the natives. Women in the Village who met with Irewa also said that,

Land, forests, and water are the source of life. Good for humans, animals, plants, and other living creatures. The local indigenous people have a history for generations ... the relationship between land and people is like mothers and blood. Give breath and life to human beings from birth. Growing up till die. Hence land and forests must be preserved, protected, managed, and utilized for the continuation of human life. The mamas in the village said that the land is their biological mother.(Herliany, 2015:163).

What the women said was in keeping with the view of ecofeminism for linking the land and forest with the mother and the blood that gives the breath of life, so it must be maintained, managed, and utilized for the continuation of human life. Destroying the land and forests, thereby means killing meaningful life and preventing the emergence of the next generation.

The novel Lemah Tanjung by Ratna Indraswari Ibrahim clearly illustrated the deconstruction of the patriarchal power over nature, the environment, and women. This novel tells the story of a community, led by Mrs. Indri against the eviction of green land belonging to the Academy of Agricultural Extension (APP) Malang which would be transformed into an elite settlement. This novel was actually inspired by a true story. The novel was inspired by the struggle of the residents of APP, Mrs. Hiendrarsih who refused the relocation and opted to stay in her house in the complex of the Ministry of Agriculture campus of APP while rge investors still do a swap to convert the former area of the campus into the luxurious housing. One APP land that is near the campus of UNM (University of Malang) has now become Malang Town Square (Janan, 2011). Lemah Tanjung has an area of 28.5 hectares; the APP complex is an urban forest. Inside are a heterogeneous forest, coffee plantations, palm oil, corn fields, rice paddies, and an open grass field. The forest is also a house for at least 128 species of plants, some of which have not been identified and become the shelter of no less than 36 species of rare birds (Djaman, 2011).

The deconstruction of the patriarchal power over nature, the environment, and women in Lemah Tanjung is evident from the struggle of Ms. Indri and her comrades; environmental activists who reject the land transfer of Lemah Tanjung into an elite area. In the novel, it can be said that Mrs. Indri was positioned as the front position in Lemah Tanjung against the land turn over into an elite neighborhood in the city of Malang.

Mrs In 'eyes dazed. "When the developer will turn this campus, I felt shocked and could not sleep. I am trying to write a letter to the Department of Forestry, mail box 5000, so that they stop the land turn over. I also send the exact letter to all departments...(Ibrahim, 2003:24).

The developer who already paid and completed the paperwork of the turn over, still erected fences though they knew that there are still people living there: Mrs Indri, Mr. Rahmat, and Mr. Samin...(Ibrahim, 2003:39).

In Indonesia, there are many cases of development that often sacrificed the interests of the people and do not follow environmental ethics, one of them is the land conversion of APP into Malang Town Square, Ijen Nirwana Regency, Malang Olympic Garden, and some gardens into office buildings (Djaman, 2011). People have been trying to prevent the environmentally destructive construction, but it always ends in a failure.

Ilham explained while shooking his head, "people are saying only the authorities can cancel the land turn over. We've complained about the problem to the House of Representatives there. Both the House and Sarwono, who was the Minister of the Environment, considered the land which is full of rare trees should still be the medium of education. "I saw anger when Ilham uttered those words. (Ibrahim, 2003:5).

We stood in front of the Parliament building. The security forces had wanted to banish us.... an activist of Lemah Tanjung APP read the demonstrators petition that the turn over was one-sided because it is legally flawed. Mrs In 
replied, that the educational area should not be given to a handful of rich people.... (Ibrahim, 2003:41).

By portraying the struggle of Mrs. Indri and the environmental activists to reject theland turn over of Lemah Tanjung, it is clear that the novel was deliberately written to criticize capitalism and patriarchy on women and nature, which is equivalent to the perspective of ecofeminism. Mrs. Indri's defeat in defending APP campus land and the land conversion showed strong patriarchal power over nature and women. As stated by Tong (2006: 360) that if the men had been given power over nature, then he has not only control over the nature, but also over women.

Another novel which shows the authors one-sidedness on violence and oppression against nature, which directly or indirectly would be disadvantageous to women is Partikel (Dee / Dewi Lestari). This novel tells the struggle of Zarah and her friends in the rescue mission of nature and the environment. In a photographic travel to Tanjung Puting, Kalimantan, Zarah acquainted herself with Mrs. Inga Dominykas, a female citizen of Canada who dedicated herself as a researcher and caretaker for the orangutans in Kalimantan. Zarah was so amazed by Mrs. Inga's struggle in conserving orangutans, so she was keen to help Mrs. Inga take care of the forests in Tanjung Puting. Tanjung Puting is a national park located on a peninsula in Central Kalimantan and is the biggest orangutan conservation in the world, with the population of an estimated 30,000 to 40,000 otangutans scattered inside and outside the park, Tanjung Puting is also a designated biosphere reserve since 1977 with its core areas covering 415,040 acres set up in 1982. With such status, Tanjung Puting could be preserved. To go to this park, people need down the Sekonyer River by boat. (http://www.alambu-daya.com/2012/07/taman-nasional-tanjungputing.html?m=1). In Tanjung Puting, Zarah followed the footprint of Mrs. Inga to become a babysitter for an orangutan named Sarah.

With her profession as a nature photographer, Zarah works on The A Team Wildlife documenting numerous species of flora and fauna from around the world through her camera lens. Wildlife Photography is a type of photography that captures the moment of various wildlife behaviors in their natural habitat. (http://www. rancahpost.co.id). The purpose of this photography is to take photos of interesting animals when they are doing activities such as eating, flying, or fighting. To take photos of wildlife in their activities, a photographer uses a long telephoto lens and takes a photo of the object from a distance (http://www.infofotografi.com/blog).

Together with his co-worker (Paul), Zarah gets an understanding that a wildlife photographer has a noble mission to introduce the earth and everything in it to many people.

"... If you do not take this photo, how can we know what eye contact with crocodiles mean? Not everyone can withstand months stalking polar bears in the Arctic. If no one is doing it, how people in other parts of the world could know the importance and beauty of the polar bear? For me, wildlife photography is a bridge for people to get to know their own home. This Planet Earth. I see our profesion as an important bridge that connects Earth and the human population. We're the ambassador of nature. "(Dee, 2012: 253).

From the dialogue between Zarah and Paul in the quotation above, it appears that a wildlife photographer has the noble duty as a bridge linking the man to the earth with all its beauty, which people might not know about. Additionally, to get an image which is natural and unique, photographic teams often join other humanitarian missions, such as the orangutan conservation team in Tanjung Puting. When joining a humanitarian mission team, of course, the photographers will also understand better the various realities of life occurred in various parts of the world, so they are also involved in that humanitarian mission. That is what Zarah encountered while doing her first assignment from her team.

Seven weeks I have been in London. My first task finally arrived. Kenya.

I will join the team from FAO for a donation of food, while at the same time recording the food crisis that hit Kenya due to the prolonged drought. The period of my work is not to be taken lightly. Three months. Paul just will accompany me in the first week. The rest, I am alone ... (Dee, 2012: 292)

Involving wildlife photographer's team members in various activities of humanitarian missions is one of the ways employed by The A Team led by Paul. This is consistent with their vision that wildlife photography is a bridge for people to get to know their own home.

If there is a medical journal research to Africa to study AIDS, for example, to be a team of bodyguards to the researchers, Paul will put one of his colleagues. His job may not only to take pictures, but also to be busy to be on call anytime. The payment is also not great. But, the photographer will be benefited with a free opportunity to go into the wild as he wanted, taking good photographs, and from there he will have the start up to his career. (Dee, 2012: 243).

By describing the activities carried out by the wildlife photographer of Zarah's The A Team, Partikel seems to 
want to express the importance of humans involved in the rescue mission of human and nature through their chosen profession. Zarah and her friends did their role through photography, Mrs. Inga lead her role through research and the protection of orangutans in the depth of Borneo.

Zarah was enjoying her profession as wildlife photography. This certainly cannot be separated from the lessons learned from her father, Firas who was known as a scientist and researcher bred various types of useful plants, including medicinal plants at Luhur Batu village, Bogor. Zarah's father pioneered the cultivation of land in the village without the use of chemical fertilizers and synthetic drugs and permaculture planting system that does not destroy and eliminate the fertility of the soil.

In Batu Luhur there is no critically degraded land whether during the dry or rainy season. Since Dad stopped the use of chemical fertilizers and synthetic drugs, he rehabilitated the top layer of soil in the fields of with mycelium...

One by one, the concept of cultivation in Batu Luhur also changed. There is no homogeneous crop, father called it permaculture, the villagers called it "jumbled field." From the name, the villagers initially assumed that permaculture was a joke ... (Dee, 2012: 25-26).

In addition to describing the activity of a number of characters in the rescue of nature and the environment, as well as the campaign of loving the nature through wildlife photography, the novel Partikel also criticizes the environmental damage occured in the Sekonyer River, Kalimantan due to the pollution from the gold mine waste.

Duyung began to enter the right part of Sekonyer deeper. The river starts to get narrow. Dense vegetation consumed the stream from each side. Mr. Mansyur said that if the stream is accidentally opened by the residents and tourism, Right Sekonyer could suffocate from the vegetation itself.

Again, our group gasped to see the color of the water changed drastically. We seemed to sail in black glass. The black color was caused by a tannin substance from tree litter and humus peat. Throughout the eye can see, it is all blue sky, white clouds, green forest clearly reflected in the water ... (Dee, 2012: 228).

Ten years ago, there were scenes of people fishing on the riverbank. Now almost no more. Freshwater fish such as snakehead fish, mudfish, and arowana disappeared dramatically.

"If the fish is not able to live here, other animals will follow," said Mr. Mansyur flatly. His eyes gazed. Such conditions paralyzed him (Dee, 2012: 180-181).

From these quotations, it seems that the criticism of the environmental damage is delivered through the character of Mr. Mansyur. If such damage is not addressed, it will certainly result in the extinction of animals and biodiversity in the nature of Borneo. Through Zarah's character, these novels also presents the environmental damage caused by human activities occurred also in the Pacific Ocean. Man arbitrarily injures nature without realizing it will become a suicide bomb for the man himself.

The Great Pacific Garbage Patch or the Pacific Trash Vortex started to become a concern when a few years ago a sailor found concentrations of trash in a gigantic size floating in the North Pacific Ocean. People had noisily called it "The most massive man-made objects ", beating the Wall of China. Twice the size of the French. And potentially keeps getting bigger...

Anyone who saw the form of Pacific Trash Vortex will find this Earth has no future, so are the prevalent opinions. Hearing it, I smiled plainly. I've always felt this place has no more future...

The budget of the garbage reduction in the Pacific is far behind the latest James Bond film budget, Zach then joked. In our heart, we realized that it was a serious problem ... (Dee, 2012: 375-376).

By choosing Zarah as the main character in Partikel, a woman who is in love with the nature and the environment, it appears that the novel is written from the perspective of ecofeminism. By placing Zarah as a figure involved in the campaign and the action to save the environment, including the orangutan, the novel brought the idea of ecofeminism as expressed by Maria Mies and Vandana Shiva that women have been led to rescue the basics of life anywhere and anytime when the industrial and military interests threaten (Tong, 2006: 394).

In the novel of Amba by Pamuntjak Laksmi, the deconstruction of the patriarchal power over nature and the environment is shown in actions carried out by Second Woman (The Bird Face). Forests are considered as friends by the Second Woman. The character found peace in the middle of the forest. In fact, she was often in dialogue with the trees in the forest and criticized the uncontrolled deforestation, as shown in the following excerpt. 
The Second Woman seeks peace in the middle of the forest. (She decided "to stare at the moon"). It is told that lately that she feels need to do it, not only to "stare at the moon", but also to occasionally get out of the dense jungle, towards the light, into a small field in the middle of the woods. She felt the need to go out there, even when she knew there was no one who could saw herself in luminous plots distributed in the dark. She also wants to freely greet the trees that are increasingly threatened. Because the loggers come more often...(Pamuntjak, 2012: 17).

In $A m b a$, it is told that the Second Woman hugged the trees while whispering:

Feel the warmth of my body, feel my heart pounding I was so in love with you. And she hugged the trees so long, with tears. She hugged them as First Woman hugging the dirt mound with the tears that hasten rain. Again, this is not weird for the villagers of Kelapa Air. They generally know that the trees that have been marked by the Second Woman were not only cut off from the land, but also transported in trucks often with no plates, to unknown places by unknown people ... (Pamuntjak, 2012: 17-18)

The conversation and pressing her body to a tree as performed by the Second Woman in the perspective of ecofeminism of Verdana Shiva is known as the Chipko movement, a Hindi word which means "embrace". According to Shiva, the Chipko movement began in 1974 when twenty-seven women in northern India struck a prostest by tying themselves to trees if the chain saw tried to cut trees (Tong 2006: 349). Women need to save the forests because they have a relationship with the rural economy and households. Forests are related to the provision of food, fuel, food storage, the products to meet the needs of household, and as a source of income (Tong, 2006: 349).

By taking the setting of Borneo Bunga dan Api Awan Asap Korrie by Layun Rampan also depict the struggle of the characters involved in nature conservation and land utilization in accordance with local knowledge and to boost the productivity of society. In the Bunga the characters are a married couple, Bunga and Prasetya. In Api Awan Asap these figures are Jepi the officer, his son (Nori) and his daughter in law (Jue). As a writer who comes from Samarinda, East Kalimantan, Korrie Layun Rampan would seem to illustrate how the characters, especially the younger generation, had a role in the rescue and preservation of the environment in the jungle of East Kalimantan. The report of Forest Watch Indonesia (FWI) in 2001 to 2003, which became the background of the novel stated that the rate of deforestation in Borneo in the last decade was about three to four million hectares per year (antaranews.com/berita/). Such damage in the year of 2000 was allegedly associated with the enactment of Law No. 22 of 1999 on HPHH or small logging 100 Ha. From the reports submitted by the Environmental NGO Greenomics Indonesia, it is also obtained the information that $61.54 \%$ logging company operating in Kalimantan belong to the category of poor performance and are very bad in terms of sustainable timber utilization. The findings by the Executive Director of Greenomics, Elfian Effendi, is the result of an evaluation of the 40 logging companies in Kalimantan that manage concessions of total area of 3.48 million hectares (nasional.kompas.com).

In the Bunga the struggle of a husband and wife (Bunga and Prasetya) in building and developing agriculture and plantations for forest conservation efforts is depicted. For their business, they even received an award from the central government (Jakarta) as the pioneer and preserver of forests, aired on national television (Rampan, 2002: 191).

The box seemed so magical. As Bunga stepped out of the darkness, as if she came out of a ranyah and tunjang, entered the dark area with sparkling light. Then there was brightness and dreams of immortality laid on bed. A village teacher, feels so magical, speaking in a magic box, a talking box transmitting images to the entire country. As she looked at herself, her own image, Bunga felt that her face so hot, millions of eyes looking at her face from the twenty-seven provinces.

However, she has spoken.

She kept talking about the ideals of the village teacher. About the profession and development. Her tongue eloquently pronounced words, as eloquent as Prasetya's tongue that explains about the gardens and rare fruits. About the undergraduate work in the village, on the future development of his land.... (Rampan, 2002: 1.790180).

Bunga is an elementary school teacher in the village, one of the young generation with her awareness of returning back to the village after graduate. This is different from her three brothers who chose to work in Jakarta and Bontang after school / college.

Bunga is pleased to teach and educate the children of her own village, as she teaches and educate her children .... 
That is why, she really loves her job, and because the job of teaching and educating are the work containing lives (Rampan, 2002: 9).

Similarly, the married couple, Bunga and Prasetya who received an award from the government as the pioneer of environmental conservation in the interior of Borneo, in the Api Awan Asap, The officer Jepi, also received the Kalpataru award from the Department of Environment.

A year ago, officer Jepi for the first time, stepped in Jakarta. According to the experts in Jakarta, he has done something useful for the preservation of the environment. Dempar village that he built when he had not yet reached the age of twenty, already showed signs of steady progress in the future.... "Who is your motivator that caused the idea to build the village as it is now?" Asked a television reporter in Samarinda after officer Jepi returned from Jakarta to receive Kalpataru. "The main motivator is the tradition of our ancestors."

"The tradition of the ancestors?"

"Yes then combined with modern techniques developed by my son-in-law, Jue."

"What do you mean with the traditions of the ancestors?"

"People here never indiscriminately do logging. Like humans, the natives looked at the ground, roots, trees, and the leaves as a soul. The trees in the forest could be cut and retrieved according to the needs of the villagers. Ploughing soil as needed. Limiting the hunting of animal only based on the protein needs.... "

(Rampan, 1999: 12-13).]

From these quotations, it shows how officer Jepi blends the ancestral traditions in organizing the management of forest combined with modern techniques. Moreover, because they believe nature also has a soul, then the use must also be limited to that of necessary. Jepi also said that the people understand that the forest is divided into six parts. Having regard to the allotment of six parts of the forest, the forestry sustainability can be maintained.

"Tradition has it that these lands are divided into six kinds of designation."

"Six? Six kinds of allotment for what...? "

"To determine the specific location. Which part may be encroached upon and turned into fields, which part should only be as a protected forest. "

"What do you mean?"

"Here. In the Lou region, there is a patch land devoted to be planted with certain fruits, such as lai, durian, olive, encepm payakng, encepm boelau, keramuq, rambutan, jackfruit, rekep, Siwo, and so forth. That region is permanent forest that should not be violated by anyone. All residents are the owners, although the trees may only be planted by the officer or one of the Lou residents. "(Rampan, 27)

"The third circle of tradition is na area that is intended for dry fields. Once the area was cleared, rice will be planted, if it is deemed infertile, then the villagers will open a new land adjacent to the old one. And so on.... (Rampan, 1999: 28)

"So there is a certain wisdom in treating the forest and soil?"

"That is the wisdom that makes people unable to do logging indiscriminately ... But the people came from town greedily cleared the forest, take the tree, dig mines, and open land, burn forest until the smoke covered the sky. You see clouds hanging and but not containing rain overcast, that is the clouds of smoke from the fire that came from the land of the rich city folks. "(Rampan, 1999: 30).

In Api Awan Asap it is also told of Nori's efforts to maintain idle land into productive land which provides income to the local community. Nori, from her efforts, was able to change people's views of an abandoned lake that is supposedly haunted.

In the eyes of Nori, the lake was not the result of a damned or a curse but a natural process that came from volcanic eruptions. When his father opened the way to it, in his mind no longer believe in the myth of their ancestors. But swiftly he thought to open the land surrounding the lake as an agricultural area, after he saw with his own eyes the condition of the land ... In his mind, the lake would be a perfect place for attractions, such as that he had seen in Sarangan, when his school conducted field trip ...

The first time he planned to show it to his father, officer Jepi shook his head.

"You know the area is haunted. How did you even make plans that seem to make no sense? "I have an idea for the lake and the land. I do not want to ask you a favor, Sa. Even the soils around it might be allotted as 
that I want. "

"Your capital?" His father felt the idea was very burdensome. Rattan and rubber left by Jue in lou Ulu. Did not his own father had a large plantation there?"

"Indeed there is. You yourself harvest it. If it's your plan, dad would not prohibit. "(Rampan, 1999: 42).

The work done by Nori turned out to bring many benefits to society. Thanks to the management of the lake and surrounding area, people have electricity, in addition to supplying the irrigation of agricultural land and fisheries. Even Nori also invited the villagers to raise poultry that can be used for consumption and sold (Rampan, 1999: 115).

By depicting the characters engaged in environmental protection activities and the utilization of nature, especially forests productively without abandoning the values of local wisdom in the interior of Borneo, it appears that both novels of Rampan were written with an awareness of ecofeminism, especially by giving an important role to a female character, Bunga and Nori who cooperated with the father and husband in environmental conservation activities. In both these novels, it seems that Rampan was carrying liberal ideas ecofeminism because it considers that the responsibility for the maintenance of nature and the environment is a shared responsibility of all human beings, men and women.

\subsection{Ecofeminism as the Basic Aesthetic Writing of the Novel}

Based on the study and discussion of ten novels as the source of the data, it is showed that the ten novels raised the issue of ecofeminism as the underlying theme of the story. The series Bilangan Fu (consists of Bilangan Fu, Manjali dan Cakrabirawa, and also Maya) raised the issue of ecofeminism to resist the power of patriarchy taking forms on the rock climbers, limestone miners, and the excessive deforestation resulting in the destruction and damage to ecosystems which directly or indirectly, will be detrimental to women. The author of the novels, Ayu Utami certainly deliberately wrote her work as a means of carrying the idea of ecofeminism, particularly those put forward by Karen J. Warren in hes book entitled Ecofeminism, Women, Culture, Nature (1977). Connecting the oppression of nature, such as that performed by the rock climbers and limestone miners, and the excessive deforestation in Sewugunung and the looting of cultural heritage in the Calwanarang temple site with the oppression of women in accordance with the perspective of Warren's ecofeminism (Tong, 2006: 388; Subono, 2014: 168). Currently, Ayu Utami has been known as a female writer who brought the issue of feminism in the novel of Saman and Larung, which were written before the Bilangan Fu series, as revealed in the previous studies (Wiyatmi, 2013). Saman dan Larung raised the issue of gender equality to deconstruct patriarchal authority in the course (history) of the Indonesian nation in the era of the New Order, which took form as a military force. Environmental issues are not a concern in both the novel. In Bilangan Fu, the environmental issues became the special concern of Ayu Utami.

Lemah Tanjung (Ratna Indraswari Ibrahim), Partikel (Dee), Isinga (Dorothea Rosa Herliany), Bunga dan Api Awan Asap (Korrie Layun Rampan), apparently were written by the authors to carry the issue of ecofeminism. The novels quite clearly raised the struggle women figures, along with a number of prominent men, against the forces of patriarchy that led to the destruction of nature and ecosystems. These characters are used by the writers to voice the deconstruction of the patriarchal power that harms nature and women, while the characters are described as activists and actors who supported the movement that regards the right to life to nature and women. The characters in the novels are given a role to improve the quality of the environment, in order to avoid gender discrimination. From the amount of data contained in the novel, it can be seen that even explicit statement linking nature with women can be found, thus the oppression of nature, directly or indirectly also could be considered as the oppression of women. Thus the resistance against the oppression of nature also means to rescue women as the victims of repression. Saving nature also means saving women.

Although not raising the issue of ecofeminism in particular, the novel Amba demonstrated the awareness of ecofeminism voiced through the activity of the two female characters in the novel. This happens because ecofeminism has become a part of the consciousness of the authors which spontaneously expressed when talking about matters related to the environment and nature. The results also showed that the presence of a number of Indonesia novels which brought the issue of ecofeminism, it can be concluded that there is an indication that in the writing of Indonesia literature, the development of literature that supports the movement of ecofeminism worldwide since 1974 initiated by Francoide d'Eaubonne through a book entitled Le Feminism ou la Mart (Feminism or Death) already took place.

\section{Conclusion}

From the results of research and discussion, it can be concluded that (1) the studied novels describe the 
deconstruction of the patriarchal power that led to the massive exploration and exploitation of natural resources and cultural heritage and to disremember the values of local wisdom, (2) the novels show a tendency written by the authors with ecofeminism perspective who understood that the violence against nature is synonymous with the violence against women.

\section{References}

Alwi, Q. (2007). Cultural Theme as The Background Force that Drove the Native Women's Behavior during Pregnancy and Childbirth in the Mimika Regency. Buletin Penelitian Kesehatan, 35(3).

Candraningrum, D. (2013). Ecofeminism in the Interpretation of Religion, Education, Economy and Culture. Yogyakarta: Jalasutra.

Dee (Dewi Lestari). (2012). Partikel. Yogyakarta: Bentang.

Djaman, B. (2011). Mbak Ratna, Sang Penulis, Sang Pejuang Lingkungan Hidup. dalam blog.ub.ac.id/bachtiardm/2011. Retrieved July 30, 2016, from google.com

Dumatubun, A. E. (2002). Kebudayaan, Kesehatan Orang Papua dalam Perspektif Antropologi Kesehatan. dalam Antropologi Papua. Retrieved July 25, 2016, from https://papuaweb.org/uncen/dlib/jr/antropologi

Gaard, G., \& Murphy, P. D. (1998). Ecofeminism Literary Criticsm, Theory, Interpretation, Pedagogy. USA: Board of Trustees of the Universuty if Illionis.

Herniany, D. R. (2015). Isinga, Jakarta: Gramedia.

http://www.alambudaya.com/2012/07/taman-nasional-tanjung-puting.html?m=1. Retrieved July 25, 2016, from google.com

http://www.antaranews.com/berita/2275/ancaman-bagi-hutan-kalimantan-belum berakhir. Retrieved July 25, 2016, from google.com

http://www.indonesiatimur.com, 2013/09/25, “Tradisi Blood Taboo Persalinan Masih Berlaku,” Retrieved July 25, 2016, from google.com

http://www.infofotografi.com/blog. Retrieved July 25, 2016, from google.com

http://www.nasional.kompas.com/greenomics: kinerja pemegang hph Kalimantan buruk. Retrieved September 2008, from google.com

http://www.pemkab.papua.go.id/data_geografis.php, Retrieved July 25, 2016, from google.com

http://www.ptfi.co.id/about, Retrieved July 25, 2016, from google.com

http://www.rancahpost.co.id Retrieved July 25, 2016, from google.com

https://www.kabarpapua.co/penularan-hivaids, "Penularan HIV/AIDS di Papua Lebih Banyak Melalui Seksual,"

Retrieved July 25, 2016, from google.com

Ibrahim, R. I. (2012). Lemah Tanjuang. Jakarta: Gramedia.

Jurnal Perempuan Nomor 80, (2014). Women's Body in Ecology. Jakarta: Yayasan Jurnal Perempuan.

Pamuntjak, L. (2012). Amba. Jakarta: Gramedia Pustaka Utama.

Pattiselanno, F. (2004). Pig as a Fertilizing Livestock. Retrieved July 30, 2016, from https://www.Papuaweb.org

Piliang, Y. A. (2012). Hipersemiotics: A Cultural Studies Interpretation of the Death of Meaning. Yogyakarta: Jalasutra.

Rampan, K. L. (1999). Api Awan Asap. Jakarta: Gramedia.

Rampan, K. L. (2002). Bunga. Jakarta: Gramedia.

Sarup, M. (2003). Postrukturalisme dan Postmodernisme, Sebuah Pengantar Kritis. Yogyakarta: Jendela.

Sekarningsih, A. (2006). Namaku Teweraut. Jakarta: Yayasan Obor Indonesia.

Tong, R. P. (2006). Feminist Thought: A More Comprehensive Introduction. Translated into Indonesian by Aquaini Priyatna Prabasmara. Bandung: Jalasutra.

Utami, A. (1998). Saman. Jakarta: Kepustakaan Populer Gramedia.

Utami, A. (2001). Larung. Jakarta: Kepustakaan Populer Gramedia.

Utami, A. (2008). Bilangan Fu. Jakarta: Kepustakaan Populer Gramedia. 
Utami, A. (2010). Manjali dan Cakrabirawa. Jakarta: Kepustakaan Populer Gramedia.

Utami, A. (2013). Maya. Jakarta: Kepustakaan Populer Gramedia.

Walby, S. (2013). Patriarchy at Work. UK, Cambridge: Polity Press.

Warren, W. J. (2000). Ecofeminism Philoshophy. USA: Rowman \& Littlefield Publishers, Inc.

Wiyatmi. (2013). The Struggle of Women in Education and Health in the Rural Areas in the Novel of Namaku Teweraut by Ani Sekarningsih. In the Feminist Literary Criticism: Theory and Application. Yogyakarta: Ombak.

Wiyatmi. (2014). Nature and Environments in the Novel of Amba by Laksmi Pamuntjak: An Ecocriticism Study. Yogyakarta: Fakultas Bahasa dan Seni, Universitas Negeri Yogyakarta.

\section{Copyrights}

Copyright for this article is retained by the author(s), with first publication rights granted to the journal.

This is an open-access article distributed under the terms and conditions of the Creative Commons Attribution license (http://creativecommons.org/licenses/by/4.0/). 